Rozwój Regionalny i Polityka Regionalna 48: 9-22 https://doi.org/10.14746/rrpr.2019.48.02

Roman Matykowski ${ }^{1}$, Kamila Zmudzińska

${ }^{1}$ Uniwersytet im. Adama Mickiewicza $w$ Poznaniu

Wydziat Geografii Społeczno-Ekonomicznej i Gospodarki Przestrzennej

rommaty@wp.pl,kzmudzinska165@gmail.com

\title{
Wybory do Parlamentu Europejskiego w 2019 r. w województwie wielkopolskim: zróżnicowanie przestrzenne na poziomie subregionalnym
}

\begin{abstract}
Zarys treści: Celem opracowania jest charakterystyka orientacji politycznych elektoratu województwa wielkopolskiego w wyborach do Parlamentu Europejskiego w dniu 26 maja 2019 r. w przekroju terytorialnym 35 powiatów. Na podstawie wskaźnika proporcji poparcia dla dwóch czołowych komitetów wyborczych wyznaczono obszary przewagi Komitetu Europejskiego oraz Prawa i Sprawiedliwości. Zwrócono też uwagę na rolę kandydatów „nierodzimych” w różnych częściach województwa, uważanego za przykład zbiorowości o silnych postawach regionalistycznych.
\end{abstract}

Słowa kluczowe: wybory do Parlamentu Europejskiego, zróżnicowanie przestrzenne wyborów, kandydaci nierodzimi a regionalizm, województwo wielkopolskie

\section{Wprowadzenie}

Wybory do Parlamentu Europejskiego nie cieszyły się dużym zainteresowaniem uprawnionych do udziału w nich mieszkańców Polski. W pierwszych bezpośrednich i powszechnych wyborach do Europarlamentu w dniu 13 czerwca 2004 r. wzięło udział tylko 20,87\% ogółu uprawnionych, a w kolejnych w dniu 7 czerwca 2009 r. $-24,53 \%$ oraz w dniu 25 maja 2014 r. - 23,83\% (tab. 1). Dopiero ostatnie wybory do Parlamentu Europejskiego w dniu 26 maja 2019 r. przyniosły zmianę zachowań, gdyż wzięło w nich udział aż 45,68\% uprawnionych, a frekwencja zbliżyła się do poziomu uczestnictwa w wyborach do parlamentu krajowego.

Decyzją Rady Unii Europejskiej z dnia 25 czerwca i 23 września 2002 r. w akcie dotyczącym wyborów do Parlamentu Europejskiego deputowani są wybierani w powszechnych wyborach bezpośrednich w oparciu „o formułę proporcjonalną z zastosowaniem systemu list lub pojedynczego głosu przechodzącego" 
(zob. Glajcar 2009, s. 51). Z kolei reguły wyboru deputowanych do parlamentu w Polsce określała w pierwszych dwóch elekcjach ustawa Ordynacja wyborcza z dnia 23 stycznia 2004 r., a następnie Kodeks wyborczy z dnia 5 stycznia 2011 r. w dziale VI (art. 328-368). Regulacje unijne ograniczyły wielkość progu wyborczego na poziomie krajowym do $5 \%$ i taką też maksymalną wartość przyjęto w wyborach w Polsce. Polska została podzielona w wyborach do Parlamentu Europejskiego na 13 okręgów, z których siedem składało się terytorialnie z jednego województwa, cztery tworzyły dwa sąsiednie województwa, a województwo mazowieckie podzielono na dwa okręgi: nr 4 (obejmujący aglomerację stołeczna) i nr 5 (pozostała część województwa). Okręg nr $7 \mathrm{w}$ tym podziale stanowi województwo wielkopolskie.

Celem opracowania jest charakterystyka zróżnicowania zachowań politycznych elektoratu $\mathrm{w}$ województwie wielkopolskim w wyborach do Parlamentu Europejskiego w dniu 26 maja 2019 r. Jednakże badania tego typu zachowań mieszkańców Wielkopolski zostały sprowadzone do kilku zagadnień szczegółowych, takich jak:

1. zróżnicowanie przestrzenne poparcia dla największych ugrupowań politycznych oraz mechanizm tych zmian w latach 2004-2019;

2. poziom poparcia dla kandydatów nierodzimych w układzie powiatów w świetle rozwiniętych postaw regionalistycznych;

3. rola i siła wpływu liderów - lokomotyw wyborczych w układzie powiatów.

\section{Założenia teoretyczno-badawcze: sposób analizy}

Studia przestrzenno-elektoralne poszerzały swój zakres badawczy, obejmując $\mathrm{m}$.in. zagadnienie uczestnictwa $\mathrm{w}$ wyborach, organizacji terytorialnej wyborów i jej wpływu na podział miejsc czy zmienności przestrzennej poparcia kandydatów lub partii (zob. Krawczyk i in. 1993). Problematykę zróżnicowania przestrzennego poparcia oraz czynników wpływających na tę zmienność Taylor i Johnston (1979) w klasycznym opracowaniu „Geografia wyborów” określają mianem geograficznego wpływu na wybory. $\mathrm{W}$ analizach przestrzennych wyborów podejmuje się próby określenia współwystępowania czy współzależności pomiędzy wskaźnikami elektoralnymi a innymi wielkościami, które często uznaje się za czynniki kształtujące ich zmienność (zob. Matykowski 1997). Do pomiaru stopnia współzależności pomiędzy wskaźnikami elektoralnymi a innymi cechami wykorzystuje się najczęściej analizę korelacji lub sięga do współczynnika związania geograficznego i w ten sposób określa się raczej siłę oddziaływania czy zależność o charakterze stochastycznym niż związek przyczynowo-skutkowy.

W analizie geograficzno-elektoralnej często wyróżnia się dwa rodzaje czynników (por. Matykowski, Tobolska 1996): (1) endogeniczne - dotyczące oddziaływania pomiędzy pewnymi wielkościami elektoralnymi; (2) egzogeniczne - dotyczące wpływu cech społeczno-ekonomicznych czy też uwarunkowań przyrodniczych, historycznych i kulturowych na wielkość wskaźników elektoralnych. Koncepcja wyjaśniająca zróżnicowanie przestrzenne zachowań wyborczych 
- zarówno w układzie subregionalnym (czyli powiatowym), jak i regionalnym (okręgów wyborczych, województw itp.) - jest związana z rywalizacją i konfliktami wewnątrz systemu politycznego kraju i odwołuje się do Rokkanowskiego modelu struktury podziałów politycznych (Lipset, Rokkan 1967, Rokkan 1970, Surazska 1994, Zarycki 1997). Z kolei oddziaływanie czynników egzogenicznych uwzględniają (1) koncepcje uwarunkowań historyczno-kulturowych, odwołujące się do pojęcia podłoża historycznego (zob. Bartkowski 2003) i (2) koncepcje modernizacyjne, analizujące wpływ niektórych czynników społeczno-ekonomicznych (Matykowski 1997, Zarycki 1997). Do tej pierwszej kategorii można również zaliczyć koncepcję uwarunkowań społeczno-kulturowych, odwołującą się do pojęcia regionalizmu. Według Kwiatkowskiego (1984) zjawisko regionalizmu może się przejawiać jako (1) stan świadomości społecznej zbiorowości zamieszkującej określone terytorium czy też jako (2) ideologie i ruch społeczny, dla którego istotną przesłanką rozwoju jest świadomość regionalna mieszkańców danego terytorium. Świadomość regionalna - według Rykla (1985) - jest częścią świadomości społecznej, która odnosi się do poczucia odrębności własnego regionu lub własnej grupy regionalnej, a według Skorowskiego (1999) - do osobistych i subiektywnych odczuć człowieka, w formie m.in. więzi uczuciowej z regionem. Do zbiorowości o silnym poczuciu odrębności terytorialno-kulturowej i manifestowaniu postaw regionalistycznych w Polsce zalicza się najczęściej Górny Śląsk, Kaszuby (i Pomorze), Podhale, Wielkopolskę oraz fenomen historyczny - Galicję (zob. Wódz, Wódz 1995, Sowa 1998, Malikowski 2001, Prawelska-Skrzypek, Matykowski 2001). Za pewną grupę mierników pozwalających określić natężenie regionalizmu uznaje się też wskaźniki elektoralne (Kubiak 1999).

Obok koncepcji określających wpływ czynników na zmienność przestrzenną zachowań wyborczych w naukach społecznych (w tym także na gruncie geografii społeczno-ekonomicznej i gospodarki przestrzennej) podejmuje się analizy pojedynczych regionów mające na celu wskazanie specyfiki czy odrębności w zakresie wyników wyborów oraz analizy porównawcze z własnościami elektoralnymi innych regionów podobnego typu.

W badaniach przestrzenno-elektoralnych najczęściej stosuje się zestaw wskaźników, które nie tylko bywają „miernikiem pewnej własności realnej” (Czyż 2016, s. 10), ale i w wyniku ich interpretacji przyjmują postać wskaźnika zachowań wyborczych w znaczeniu metodologicznym. Do tego standardowego zestawu wskaźników można zaliczyć zarówno poziom uczestnictwa w wyborach (czyli frekwencję wyborcza), jak i poziom poparcia poszczególnych kandydatów lub ugrupowań politycznych mierzony względem głosów ważnych uczestników. W tej analizie wykorzystano również wskaźniki poparcia partii i kandydatów na deputowanych określane w odniesieniu do uprawnionych do udziału w wyborach, aby w ten sposób zredukować wpływ frekwencji na strukturę poparcia i uznać absencję wyborczą za przejaw aktywności elektoralnej. Obok wskaźników standardowych w analizach zmienności przestrzennej wyników wyborów wykorzystano wskaźnik proporcji między głównymi partiami, który był ilorazem liczby głosów ważnych dla Prawa i Sprawiedliwości przez liczbę głosów dla Koalicji Europejskiej w każdym z powiatów (Matykowski, Kulczyńska 2016, s. 166): 


$$
w p=\frac{g_{A}}{g_{B}}
$$

gdzie:

$\mathrm{g}_{\mathrm{A}}$ - liczba głosów oddanych na partię A w powiecie (lub odsetek głosów ważnych oddanych na partię A),

$\mathrm{g}_{\mathrm{B}}$ - liczba głosów oddanych na partię B w powiecie (lub odsetek głosów ważnych oddanych na partię B).

Gdy wp przyjmuje wielkość większą od 1, oznacza to, że w danej jednostce terytorialnej wygrała ta sama partia, co w skali całego kraju; gdy wartość ta jest niższa od 1, oznacza to, że w tym powiecie rywal regionalny pokonał zwycięzcę ogólnokrajowego, a miernik ten charakteryzuje rywalizację dwóch najważniejszych ugrupowań w skali regionu.

\section{Wybory do Parlamentu Europejskiego w województwie wielkopolskim: odmienności regionalne i kontekst przestrzenny}

Podstawowymi miernikami aktywności wyborczej mieszkańców regionu jest ich uczestnictwo w wyborach oraz struktura poparcia dla najważniejszych partii (lub ich przedstawicieli). Porównując wymienione wskaźniki regionalne z ogólnokrajowymi, można ustalić podobieństwa i odmienności zachowań elektoralnych mieszkańców Wielkopolski. Frekwencja w wyborach do Parlamentu Europejskiego w województwie wielkopolskim była zbliżona do ogólnokrajowego poziomu uczestnictwa, przy czym jedynie w 2004 r. była nieznacznie wyższa od tego poziomu (tab. 1).

Tabela 1. Frekwencja w wyborach do Parlamentu Europejskiego i Sejmu RP

\begin{tabular}{|c|c|c|c|c|c|}
\hline \multicolumn{6}{|c|}{ Frekwencja w wyborach (w \%) } \\
\hline \multicolumn{3}{|c|}{ do Parlamentu Europejskiego } & \multicolumn{3}{|c|}{ do Parlamentu RP } \\
\hline $\begin{array}{c}\text { rok } \\
\text { wyborów }\end{array}$ & Polska & $\begin{array}{l}\text { województwo } \\
\text { wielkopolskie }\end{array}$ & $\begin{array}{c}\text { rok } \\
\text { wyborów }\end{array}$ & Polska & $\begin{array}{l}\text { województwo } \\
\text { wielkopolskie }\end{array}$ \\
\hline 2004 & 20,89 & 21,22 & 2005 & 40,57 & 40,90 \\
\hline 2009 & 24,53 & 24,13 & 2007 & 53,88 & 55,11 \\
\hline 2014 & 23,83 & 22,43 & 2011 & 48,92 & 49,20 \\
\hline 2019 & 45,68 & 44,86 & 2015 & 50,92 & 50,16 \\
\hline
\end{tabular}

Źródło: opracowanie własne na podstawie danych Państwowej Komisji Wyborczej.

W wyborach do Parlamentu Europejskiego w 2004 r. w województwie wielkopolskim - podobnie jak w skali całego kraju - zwyciężyła Platforma Obywatelska; jednakże partia uzyskała poparcie niższe niż przeciętnie w Polsce (wskaźnik kontrastu regionalnego był niższy od 1 i wyniósł wk=0,86). Drugie miejsce w wyborach zarówno w skali kraju, jak i regionu zajęła Liga Polskich Rodzin, a trzecie 
w skali Polski ugrupowanie Prawo i Sprawiedliwość w województwie wielkopolskim zajęło dopiero piąte miejsce i zostało wyprzedzone przez koalicję Sojusz Lewicy Demokratycznej-Unia Pracy oraz przez Samoobronę (tab. 2).

Tabela 2. Poparcie dla najważniejszych ugrupowań w wyborach do Parlamentu Europejskiego

\begin{tabular}{|c|c|c|c|}
\hline \multirow{2}{*}{ Komitet wyborczy (ugrupowanie polityczne) } & \multicolumn{2}{|c|}{$\begin{array}{c}\text { Poziom poparcia } \\
\text { (w \% ważnych głosów) }\end{array}$} & \multirow{2}{*}{$\begin{array}{l}\text { Wskaźnik } \\
\text { kontrastu }\end{array}$} \\
\hline & $\begin{array}{c}\text { W skali } \\
\text { ogólnopolskiej }\end{array}$ & $\begin{array}{l}\text { w województwie } \\
\text { wielkopolskim }\end{array}$ & \\
\hline \multicolumn{4}{|c|}{ Wybory w 2004 r. } \\
\hline Platforma Obywatelska & 24,10 & 20,73 & 0,86 \\
\hline Liga Polskich Rodzin & 15,92 & 13,15 & 0,83 \\
\hline Prawo i Sprawiedliwość & 12,67 & 10,82 & 0,85 \\
\hline Samoobrona & 10,78 & 11,41 & 1,06 \\
\hline Sojusz Lewicy Demokratycznej-Unia Pracy & 9,85 & 11,90 & 1,21 \\
\hline Unia Wolności & 7,33 & 10,73 & 1,46 \\
\hline Polskie Stronnictwo Ludowe & 6,34 & 7.13 & 1,12 \\
\hline Socjaldemokracja Polska & 5,33 & 3,53 & 0,66 \\
\hline \multicolumn{4}{|c|}{ Wybory w 2009 r. } \\
\hline Platforma Obywatelska & 44,43 & 45,79 & 1,03 \\
\hline Prawo i Sprawiedliwość & 27,40 & 19,17 & 0,70 \\
\hline Sojusz Lewicy Demokratycznej-Unia Pracy & 12,34 & 14,90 & 1,21 \\
\hline Polskie Stronnictwo Ludowe & 7,01 & 8,34 & 1,19 \\
\hline \multicolumn{4}{|c|}{ Wybory w 2014 r. } \\
\hline Platforma Obywatelska & 32,13 & 32,95 & 1,03 \\
\hline Prawo i Sprawiedliwość & 31,78 & 24,38 & 0,77 \\
\hline Sojusz Lewicy Demokratycznej-Unia Pracy & 9,44 & 12,77 & 1,35 \\
\hline Nowa Prawica Janusza Korwin-Mikkego & 7,15 & 6,93 & 0,97 \\
\hline Polskie Stronnictwo Ludowe & 6,80 & 10,50 & 1,54 \\
\hline \multicolumn{4}{|c|}{ Wybory w 2019 r. } \\
\hline Prawo i Sprawiedliwość & 45,38 & 38,39 & 0,85 \\
\hline Koalicja Europejska & 38,47 & 43,25 & 1,12 \\
\hline Wiosna Roberta Biedronia & 6,06 & 7,80 & 1,29 \\
\hline
\end{tabular}

Źródło: opracowanie własne na podstawie danych Państwowej Komisji Wyborczej

W wyborach do Parlamentu Europejskiego w 2009 r. porządek partii według poziomu poparcia był w województwie wielkopolskim taki sam jak w skali kraju. Ponownie zwyciężyła Platforma Obywatelska, ale jej poziom poparcia w województwie był tym razem wyższy niż w skali Polski, gdy drugie ugrupowanie Prawo i Sprawiedliwość uzyskało niższe poparcie niż przeciętnie w kraju (wskaźnik kontrastu regionalnego dla PiS był niższy od 1 i wyniósł tylko wk=0,70). Próg $5 \%$ przekroczyły jeszcze koalicja Sojusz Lewicy Demokratycznej-Unia Pracy oraz Polskie Stronnictwo Ludowe.

W wyborach w 2014 r. do Europarlamentu na dwóch czołowych miejscach były Platforma Obywatelska oraz Prawo i Sprawiedliwość. Ponownie próg 5\% 
przekroczyły: Sojusz Lewicy Demokratycznej-Unia Pracy i Polskie Stronnictwo Ludowe oraz Nowa Prawica Janusza Korwin-Mikkego.

W ostatnich wyborach do Parlamentu Europejskiego w dniu 26 maja 2019 r. brało udział dziewięć komitetów wyborczych, a w okręgu nr 7, tj. w województwie wielkopolskim - sześć ugrupowań, ale podobnie jak w całym kraju tylko trzy przekroczyły próg 5\%. O ile w skali całego kraju zwyciężyło Prawo i Sprawiedliwość (45,38\% ważnych głosów), o tyle w Wielkopolsce utworzony na te wybory konglomerat partii opozycyjnych, skupiających m.in. Platformę Obywatelska, Polskie Stronnictwo Ludowe, Sojusz Lewicy Demokratycznej, Nowoczesną i Zielonych - nazwany Koalicją Europejską, uzyskał 43,25\% ważnych głosów. Trzecim ugrupowaniem, które uzyskało mandaty deputowanych, była Wiosna Roberta Biedronia. Poparcie nieznacznie poniżej progu 5\% uzyskały dwa komitety wyborców: (a) Konfederacja, Korwin, Braun, Liroy, Narodowcy (4,55\%) i (b) Kukiz'15 $(3,69 \%)$.

W okresie 2004-2019 w wyborach do Parlamentu Europejskiego podobnie jak w wyborach do Sejmu uwidaczniała się coraz wyraźniej rywalizacja pomiędzy dwoma ugrupowaniami: Prawem i Sprawiedliwością oraz Platformą Obywatelską (która w wyborach w 2019 r. była podstawowym składnikiem wspomnianego konglomeratu politycznego pod nazwą Koalicja Europejska), choć koncentracja głosów przez te dwa stronnictwa w województwie wielkopolskim była zawsze niższa niż w skali kraju. I tak w wyborach w 2004 r. te dwie partie zdobyły łącznie jedynie $31,55 \%$ ważnych głosów (w skali kraju nieco więcej, bo $36,77 \%$ ), a w wyborach w 2009 r. - 64,96\%. W kolejnych wyborach w 2014 r. udział tych dwóch rywalizujących partii spadł w województwie wielkopolskim do poziomu 57,33\% ważnych głosów (w skali kraju do 63,91\%), a w ostatnich wyborach w 2019 r. ponownie wzrósł do 81,64\% (przy przeciętnej krajowej-83,85\%). Ten ostatni wzrost udziału obu konkurentów politycznych jest efektem wcześniejszych sukcesów wyborczych Prawa i Sprawiedliwości w wyborach parlamentarnych w 2015 r. oraz stworzenia konglomeratu ugrupowań opozycyjnych na wybory europarlamentarne w postaci Koalicji Europejskiej.

Szczególnie wysokie poparcie Prawo i Sprawiedliwość uzyskało w wyborach do Parlamentu Europejskiego w powiatach wschodniej części województwa wielkopolskiego: konińskim $(62,75 \%$ ważnych głosów), tureckim $(60,77 \%)$ oraz kolskim $(60,45 \%)$, a w kolejnych pięciu powiatach przekroczyło próg $50 \%$, tj. w kaliskim (59,45\%), słupeckim (52,90\%), kępińskim (50,63\%), jarocińskim (50,48\%) i gostyńskim $(50,13 \%)$. Należy zwrócić uwagę, że ten kontrast pomiędzy dwoma częściami podłoża historycznego Wielkopolski występował od wykrystalizowania się współczesnej osi rywalizacji Prawo i Sprawiedliwość (Zjednoczona Prawica) versus Platforma Obywatelska (Koalicja Europejska). W pewnym uproszczeniu można uznać, że Wielkopolskę wschodnią („zaprośniańską”) tworzy siedem powiatów: kaliski, miasto Kalisz, kolski, koniński, miasto Konin, słupecki i turecki. I tak poparcie dla Prawa i Sprawiedliwości w Wielkopolsce wschodniej w kolejnych wyborach do Parlamentu Europejskiego wzrosło z poziomu 23,5\% w $2009 \mathrm{r}$. do 53,0\% w 2019 r. i było znacznie wyższe niż podobne poparcie w pozostałej części województwa wielkopolskiego. Z kolei niższe poparcie w Wielkopolsce 
wschodniej niż w pozostałej części regionu odnotowała Platforma Obywatelska (Koalicja Europejska), choć jeszcze w wyborach w 2009 r. zdobyła przewage w poparciu nad Prawem i Sprawiedliwością w części zaprośniańskiej.

Tabela 3. Poziom poparcia dla Prawa i Sprawiedliwości oraz Platformy Obywatelskiej w wyborach do Parlamentu Europejskiego w latach 2009, 2014 i 2019 w Wielkopolsce wschodniej i pozostałej części województwa

\begin{tabular}{|c|c|c|c|c|}
\hline \multirow[b]{2}{*}{$\begin{array}{c}\text { Wybory do } \\
\text { Parlamentu } \\
\text { Europejskiego }\end{array}$} & \multicolumn{2}{|c|}{$\begin{array}{l}\text { Wielkopolska wschodnia } \\
\text { (zaprośniańska) }\end{array}$} & \multicolumn{2}{|c|}{ Reszta województwa wielkopolskiego } \\
\hline & $\begin{array}{c}\text { poparcie dla } \\
\text { Prawa i Sprawie- } \\
\text { dliwości (w \%) }\end{array}$ & $\begin{array}{l}\text { poparcie dla Platfor- } \\
\text { my Obywatelskiej } \\
\text { (w } 2019 \text { r. dla Koali- } \\
\text { cji Europejskiej) }\end{array}$ & $\begin{array}{c}\text { poparcie dla } \\
\text { Prawa i Sprawie- } \\
\text { dliwości (w \%) }\end{array}$ & $\begin{array}{c}\text { poparcie dla Platfor- } \\
\text { my Obywatelskiej } \\
\text { (w } 2019 \text { r. dla Koalicji } \\
\text { Europejskiej) }\end{array}$ \\
\hline 2009 & 23,50 & 33,99 & 18,40 & 47,91 \\
\hline 2014 & 32,20 & 24,05 & 22,90 & 34,64 \\
\hline 2019 & 52,99 & 31,55 & 35,39 & 45,65 \\
\hline
\end{tabular}

Źródło: opracowanie własne na podstawie danych Państwowej Komisji Wyborczej.

Na podstawie wskaźnika proporcji można wyróżnić obszar o wysokim poparciu dla PiS, gdzie dominacja tej partii nad Koalicją Europejską jest bardzo wyraźna $(w p>1,50)$. Obszar ten tworzą powiaty: koniński, turecki, kolski, kaliski, słupecki, gostyński i jarociński (ryc. 1). Jednakże Prawo i Sprawiedliwość uzyskało więcej głosów niż Koalicja Europejska jeszcze w 13 powiatach: gnieźnieńskim, grodziskim, kępińskim, kościańskim, krotoszyńskim, leszczyńskim, ostrowskim, ostrzeszowskim, pleszewskim, rawickim, średzkim, wrzesińskim i w mieście Koninie. Tak więc w 20 powiatach województwa wielkopolskiego PiS dominował nad KE, a w aglomeracji poznańskiej (miasto Poznań i powiat poznański) i części położonej na północ od niej przeważały głosy na KE.

Należy też zwrócić uwagę, że obszarem rdzeniowym względnie wysokiego poparcia Prawa i Sprawiedliwości już we wcześniejszych wyborach do Sejmu był obszar Wielkopolski „zaprośniańskiej”. W wyborach do Sejmu w 2011 r. wskaźnikiem przewagi poparcia dla PiS (względem poparcia dla PO) cechowały się powiaty: kaliski $(1,53)$, koniński $(1,50)$, kolski $(1,46)$, turecki $(1,41)$ i słupecki $(1,06)$; natomiast wyborców dwóch miast na prawach powiatu: Konina i Kalisza charakteryzowało w tych wyborach wyższe poparcia dla Platformy Obywatelskiej. W wyborach do Sejmu w 2015 r. już w zdecydowanej większości powiatów PiS uzyskał przewagę głosów nad PO. Jedynie w 12 powiatach PO zyskała wówczas przewagę głosów nad kandydatami PiS. Były to powiaty: poznański i miasto Poznań, wolsztyński, grodziski, nowotomyski, międzychodzki, szamotulski, obornicki, wągrowiecki, chodzieski, czarnkowsko-trzcianecki oraz dwie jednostki izolowane od tego zwartego obszaru: miasto Leszno i powiat złotowski (zob. Matykowski, Kulczyńska 2016).

W zasadzie ten układ przewagi Prawa i Sprawiedliwości utrwalił się również w wyborach do Parlamentu Europejskiego w 2019 r. Nastąpiły jedynie nieznaczne zmiany w porównaniu z układem wyborów do Sejmu w 2015 r. Do jednostek terytorialno-administracyjnych o przewadze głosów dla PiS przesunął się powiat 


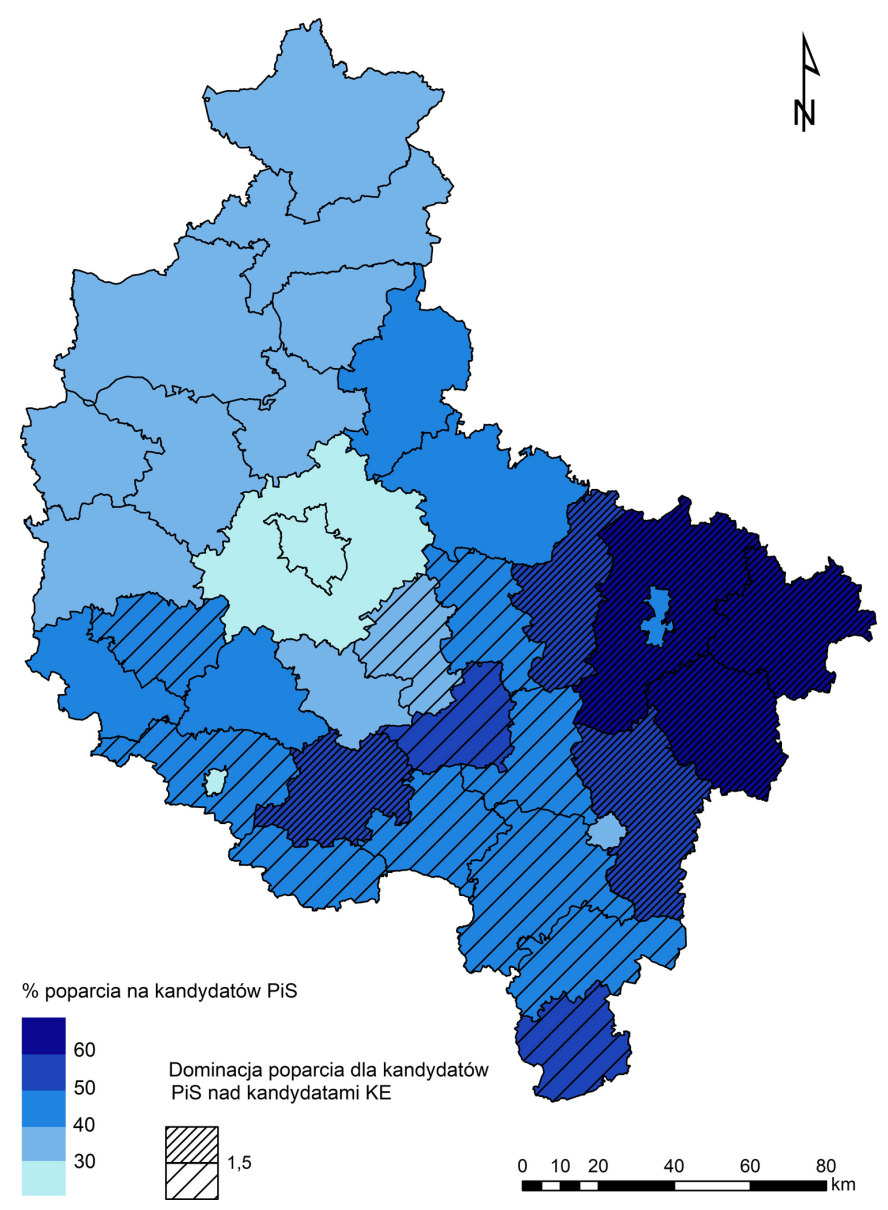

Ryc. 1. Zróżnicowanie przestrzenne poparcia dla kandydatów Prawa i Sprawiedliwości oraz obszar dominacji tej partii w wyborach do Parlamentu Europejskiego w województwie wielkopolskim w $2019 \mathrm{r}$.

Źródło: opracowanie własne na podstawie danych Państwowej Komisji Wyborczej.

grodziski, a do jednostek, w których przewagę zyskała Koalicja Europejska - dostały się powiaty śremski i pilski. O trwałości poziomu poparcia Prawa i Sprawiedliwości w województwie wielkopolskim świadczy też współczynnik korelacji określony pomiędzy stopniem poparcia tego ugrupowania politycznego w wyborach do Sejmu w 2015 r. i w wyborach do Parlamentu Europejskiego w 2019 r., który wyniósł $r=+0,873$. 


\section{Poziom poparcia dla kandydatów nierodzimych w wyborach do Parlamentu Europejskiego}

Komitety wyborcze startujące w wyborach do Parlamentu Europejskiego przyjęły różne strategie doboru kandydatów na listy okręgowe. Oczywiście dla dwóch głównych ugrupowań (Prawo i Sprawiedliwość, Koalicja Europejska) podstawową płaszczyzną była rywalizacja pomiędzy nimi i zabieganie także o sukces w skali okręgu, gdy dla ugrupowań mniejszych - przekroczenie progu 5\% głosów w skali kraju. Dlatego niektóre komitety celowo umieszczały na listach okręgowych znanych kandydatów, niepochodzących z regionu. Takich kandydatów, których formalnym miejscem zamieszkania (z obwieszczenia Państwowej Komisji Wyborczej) był inny region, określono mianem kandydatów nierodzimych („obcych”), choć czasem byli oni przejściowo związani z okręgiem (np. Marek Jurek kandydat Kukiz '15 studiował w Poznaniu).

Województwo wielkopolskie wyróżniło się pod względem takich nierodzimych kandydatów, gdyż na listach okręgu nr 7 było ich aż 11: Piotr Liroy-Marzec (Kielce) i Anna Krystowska (Warszawa) - z listy Konfederacji, Sylwia Spurek (Warszawa) z Wiosny Roberta Biedronia, Ewa Kopacz (Radom), Leszek C. Miller (Warszawa), Michał Wawrykiewicz (Dziekanów Polski) i Marek Bosacki (Warszawa) - z listy Koalicji Europejskiej, Zdzisław Krasnodębski, Joanna Lichocka i Jan Dziedziczak (wszyscy - Warszawa) z listy Prawa i Sprawiedliwości oraz Marek Jurek (Wólka Kozodawska) z Kukiz’15. Należy zwrócić uwagę, że po ośmiu kandydatów „importowanych” zgłoszono na listy okręgu nr 9 (województwo podkarpackie) i nr 12 (województwa dolnośląskie i opolskie).

Specyfiką wyborów w województwie wielkopolskim był fakt zdobycia przez 11 kandydatów obcych aż $66,86 \%$ ważnych głosów, gdy pozostali rodzimi kandydaci wielkopolscy (49 osób) uzyskali jedynie 33,14\%. Do innych okręgów, w których kandydaci importowani otrzymali widoczne poparcie, należały: nr 12 (dolnośląskie, opolskie) z 36,63\% głosów ważnych, nr 6 (łódzkie) z 21,78\% głosów i nr 10 (małopolskie, świętokrzyskie) z 18,86\% głosów. W czterech okręgach nieliczni kandydaci uzyskali poparcie poniżej 2,5\% ważnych głosów. Do tych okręgów należały dwa okręgi mazowieckie: nr 4 (aglomeracja warszawska) - 2,04\%, nr 5 (reszta województwa, przy czym kandydatów zamieszkałych w okręgu nr 4 też uznano za rodzimych) - 0,18\%, nr 8 (lubelskie) - 2,14\% i nr 11 (śląskie) - 2,29\% głosów.

Wystawienie tak licznej grupy kandydatów importowanych w województwie wielkopolskim można uznać za zaskakujące, gdyż mieszkańców tego obszaru uważa się za przykład zbiorowości o silnych postawach regionalistycznych. Jednakże rywalizacja dwóch opcji w województwie już tak widoczna w wyborach do Sejmu w 2015 r. przysłoniła elektoratowi kwestię pochodzenia kandydatów. Należy zwrócić uwagę, że kandydaci (7 osób) formalnie zamieszkali w stolicy kraju otrzymali poparcie aż 37,03\% ważnych głosów.

W dziesięciu powiatach kandydaci importowani zdobyli ponad 70\% ogółu ważnych głosów. Takimi jednostkami były cztery miasta na prawach powiatu, tj. Leszno $(77,22 \%)$, Poznań $(76,19 \%)$, Kalisz $(75,59 \%)$ i Konin $(71,74 \%)$, oraz powiaty 
środowej części regionu tworzące swoisty rogal: leszczyński (72,23\%), kościański $(74,13 \%)$, śremski $(73,33 \%)$, poznański $(75,17)$, wrzesiński $(71,48 \%)$, gnieźnieński $(74,08 \%)$ i dwa już wymienione miasta - Leszno i Poznań. Z kolei najniższe poparcie kandydaci obcy uzyskali w powiatach peryferyjnych województwa, tj. W ostrzeszowskim $(37,62 \%)$, kępińskim $(44,17 \%)$ - na południu, tureckim $(48,50 \%)$ - na wschodzie i nowotomyskim $(46,87 \%)$ - na zachodzie (zob. ryc. 2$)$.

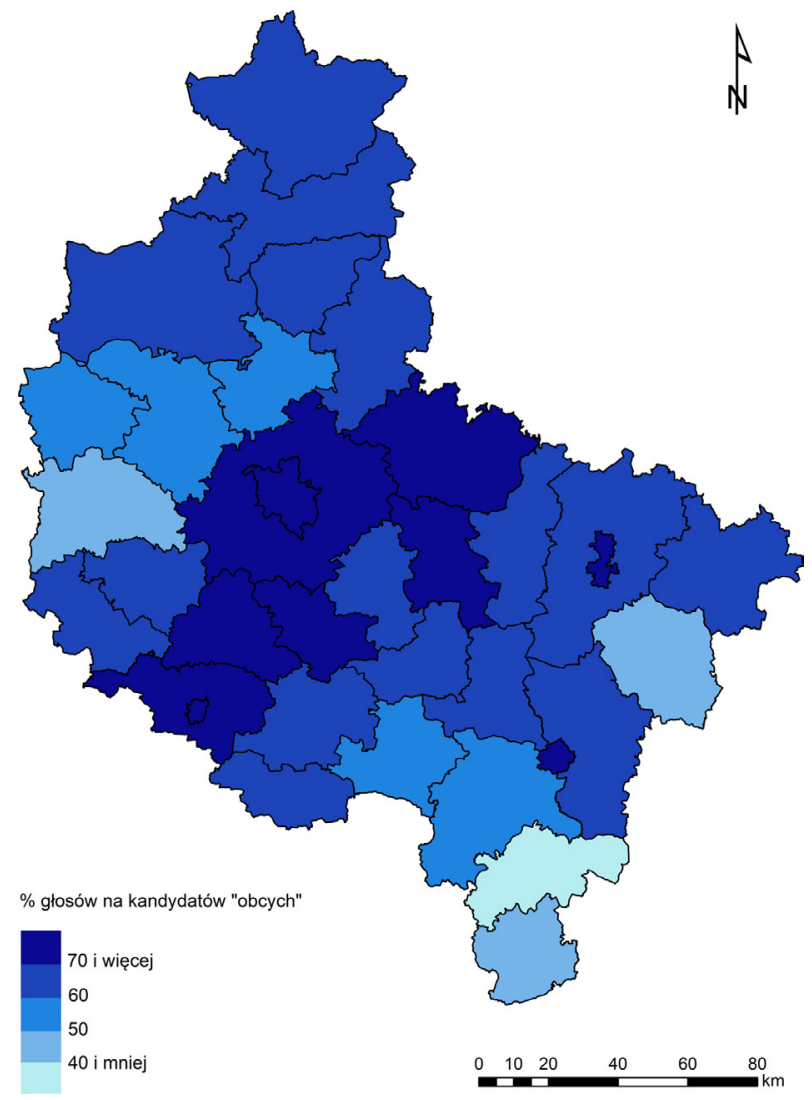

Ryc. 2. Zróżnicowanie przestrzenne poparcia dla kandydatów nierodzimych w województwie wielkopolskim w wyborach do Parlamentu Europejskiego w 2019 r.

Źródło: opracowanie własne na podstawie danych Państwowej Komisji Wyborczej.

\section{Poziom poparcia i rola kandydatów-lokomotyw}

Zaskakująca i swoista dla regionu Wielkopolski rola kandydatów nierodzimych może być po części wyjaśniona przez pozycję ujawnioną $\mathrm{w}$ trakcie wyborów do Parlamentu Europejskiego w 2019 r. Okazało się, że to właśnie kandydaci importowani uzyskali najwyższe poparcie elektoratu wielkopolskiego. Najwięcej głosów ważnych w okręgu nr 7 zdobyła Ewa Kopacz (KE), bo aż 21,01\% , a kolejne miejsca 
zajęli: Zdzisław Krasnodębski (PiS) - 13,68\%, Leszek Miller (KE) - 6,62\%, Andżelika Możdżanowska (PiS) - 6,42\%, Joanna Lichocka (PiS) - 6,07\%, Sylwia Spurek (Wiosna) - 4,61\%, Andrzej Grzyb (KE) - 4,27\%, Piotr Marzec-Liroy (Konfederacja) - 3,34\%, Marcin Bosacki (KE) - 3,28\% i Jan Dziedziczak (PiS) - 2,58\%. Tak więc w czołowej dziesiątce rodzimymi reprezentantami okręgu nr 7 byli Andżelika Możdżanowska i Andrzej Grzyb pochodzący z południowej Wielkopolski.

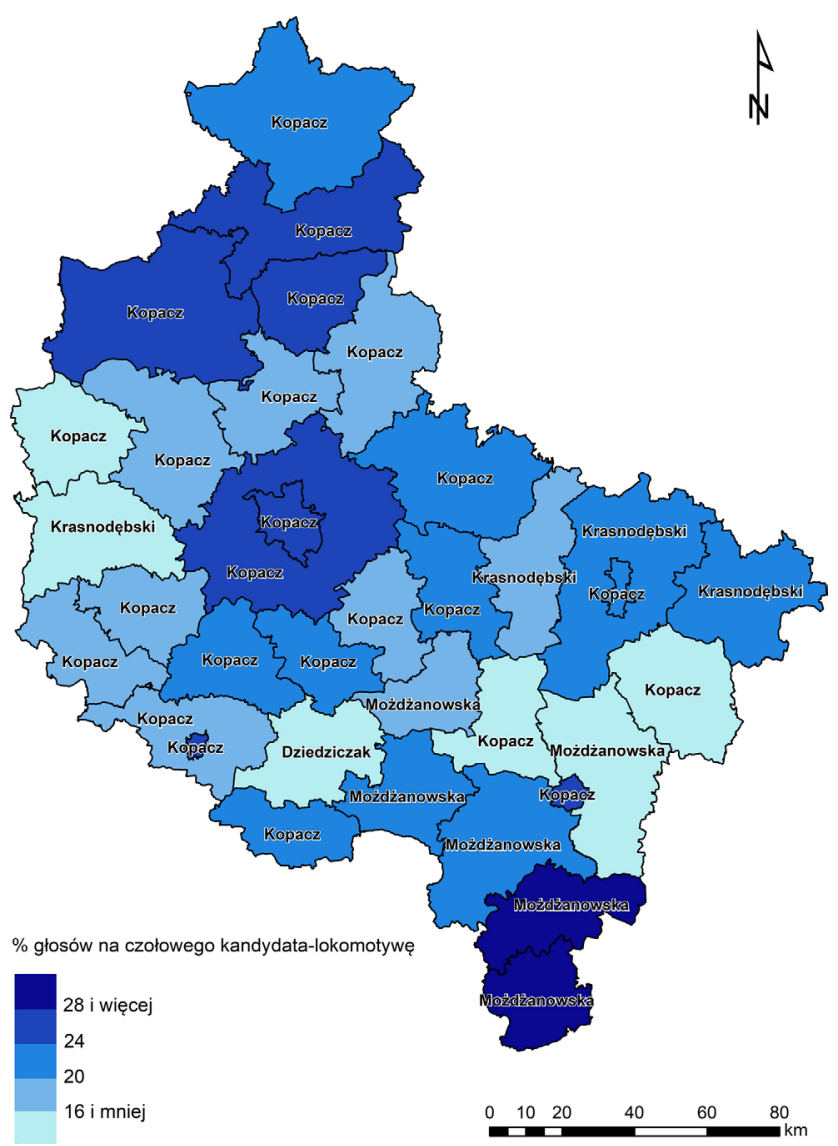

Ryc. 3. Zróżnicowanie przestrzenne poparcia kandydata, pełniącego funkcję lokomotywy w poszczególnych powiatach województwa wielkopolskiego Źródło: opracowanie własne na podstawie danych Państwowej Komisji Wyborczej.

Za kandydatów-lokomotywy uznano kandydatów na deputowanych do Parlamentu Europejskiego, którzy w danym powiecie zdobyli najwięcej ważnych głosów. Taką lokomotywą w okręgu nr 7 w wyborach do Parlamentu była Ewa Kopacz, która zwyciężyła aż w 20 powiatach (ryc. 3). Największe poparcie otrzymała ona w miastach Lesznie $(27,40 \%)$, Kaliszu (25,78\%) i Poznaniu (25,40\%) oraz w powiatach: poznańskim $(25,76 \%)$ i położonych na północy regionu - chodzieskim (25,01\%), czarnkowsko-trzcianeckim (24,40\%), pilskim (24,39\%). Należy 
zwrócić uwagę, że Ewa Kopacz zdobyła najwięcej głosów w 10 powiatach, w których Prawo i Sprawiedliwość uzyskało więcej głosów niż komitet wyborczy kandydatki-lokomotywy - Koalicji Europejskiej.

Kolejni trzej kandydaci na deputowanych do Parlamentu należący do grupy lokomotyw wyborczych reprezentowali Prawo i Sprawiedliwość. Byli to Andżelika Możdżanowska, Zdzisław Krasnodębski i Jan Dziedziczak. Andżelika Możdżanowska, pochodząca z Kępna, zwyciężyła w sześciu powiatach, które do 1998 r. tworzyły ówczesne województwo kaliskie. Najwyższe poparcie uzyskała (spośród wszystkich kandydatów uznanych za lokomotywy wyborcze) w swym rodzimym powiecie kępińskim $(35,41 \%)$, ale poza tym wygrała w powiatach: ostrzeszowskim $(28,44 \%)$, krotoszyńskim $(23,82 \%)$, ostrowskim (21,36\%), jarocińskim i kaliskim (zob. ryc. 3). Zdzisław Krasnodębski otrzymał najwyższe poparcie w trzech powiatach Wielkopolski wschodniej: kolskim (22,95\%), konińskim $(22,00 \%)$ i słupeckim $(19,25 \%)$, ale zwyciężył też w powiecie nowotomyskim, w którym najwięcej głosów zdobyli przedstawiciele KE. $\mathrm{Z}$ kolei $\mathrm{w}$ powiecie gostyńskim najwięcej głosów uzyskał Jan Dziedziczak (15,75\%).

\section{Zakończenie}

Sukces Prawa i Sprawiedliwości w wyborach do Sejmu w województwie wielkopolskim $(29,61 \%$ ważnych głosów) i uzyskanie większego poparcia niż konkurencyjna Platforma Obywatelska skłoniła obydwa rywalizujące - także w skali całego kraju - ugrupowania do przyjęcia określonej strategii przed wyborami do Parlamentu Europejskiego. I tak słabnąca politycznie Platforma Obywatelska na potrzeby wyborów europarlamentarnych powołała w skali całego kraju konglomerat partii opozycyjnych, skupiających - poza nią - także Polskie Stronnictwo Ludowe, Sojusz Lewicy Demokratycznej, Nowoczesną i Zielonych, a nazwany Koalicją Europejską. Drugim dość zaskakującym działaniem obu rywalizujących ugrupowań było umieszczenie na listach wyborczych w okręgu nr 7 importowanych kandydatów z województwa mazowieckiego, a szczególnie ze stolicy. Było to czterech kandydatów reprezentujących Koalicję Europejską (E. Kopacz, L. Miller, M. Wawrykiewicz i M. Bosacki) oraz trzech kandydatów Prawa i Sprawiedliwości (Z. Krasnodębski, J. Lichocka, J. Dziedziczak). Wydawało się, że w Wielkopolsce tak znanej z rozwiniętych postaw regionalistycznych mieszkańców (zob. Prawelska-Skrzypek, Matykowski 2001), taka strategia może się zakończyć niepowodzeniem. Jednakże nierodzimi kandydaci wszelkich komitetów w wyborach do Parlamentu Europejskiego zdobyli aż 66,86\% ważnych głosów. Okazało się to wyjątkową cechą okręgu nr 7 , gdyż w pozostałych okręgach nie ujawniła się taka rola kandydatów „obcych”. I tak na przykład w okręgu nr 11 (województwo śląskie), znanym z podobnych postaw regionalistycznych, obydwa najważniejsze ugrupowania nie wystawiły żadnego importowanego kandydata, a odważyły się na to jedynie Konfederacja (Jacek Wilk - z Warszawy) i Wiosna (Piotr Łukasiewicz $-z$ Warszawy). Kandydaci importowani uzyskali łącznie w tym okręgu $2,29 \%$ ważnych głosów. 
Co prawda w Wielkopolsce startowało sześć komitetów wyborczych, jednak niebywale silna współzależność wystąpiła pomiędzy poziomem poparcia dla dwóch głównych ugrupowań w regionie. Współczynnik korelacji pomiędzy poparciem dla Prawa i Sprawiedliwości a poparciem dla Koalicji Europejskiej w przekroju 35 powiatów wyniósł aż $\mathrm{r}=-0,965$, co oznacza, że wraz z wzrostem poziomu poparcia na jeden komitet wyborczy spada poziom poparcia na drugi. Silne związki o charakterze negatywnym wystąpiły też pomiędzy poziomem poparcia dla Wiosny a poziomem poparcia dla $\mathrm{PiS}(\mathrm{r}=-0,831)$ oraz poziomem poparcia dla Wiosny a poziomem poparcia dla KE $(r=+0,730)$ - to drugie współwystępowanie miało charakter pozytywny. Odnotowano też powiązania przestrzenne pomiędzy poziomem poparcia dla niedużej Lewicy a poparciem dla PiS $(r=-0,443)$ oraz poparciem dla Wiosny $(r=+0,500)$. Należy zwrócić uwagę, że wystąpiły związki korelacyjne pomiędzy frekwencją wyborczą a poziomem poparcia dla PiS $(r=-0,570)$ i poziomem poparcia dla $\mathrm{KE}(\mathrm{r}=+0,562)$. A zatem można na podstawie tych istotnych statystycznie (na poziomie $\alpha=0,01$ ) wspólczynników sformułować zależność występującą w województwie wielkopolskim w tych wyborach: im wyższa frekwencja, tym większe poparcie dla kandydatów KE i niższe dla kandydatów PiS. Z kolei nie wystąpił statystycznie istotny związek pomiędzy odsetkiem głosów na kandydatów nierodzimych a poziomem poparcia dwóch głównych ugrupowań, tj. Prawa i Sprawiedliwości $(r=-0,305)$ oraz Koalicji Europejskiej $(r=+0,165)$.

Podjęto także analizę skojarzeń przestrzennych pomiędzy poziomem poparcia dla dwóch głównych komitetów wyborczych, tj. Prawa i Sprawiedliwości oraz Koalicji Europejskiej, a trzema wskaźnikami uznanymi za potencjalne czynniki egzogeniczne. Związki korelacyjne pomiędzy poziomem urbanizacji w 2018 r. a poziomem poparcia dla PiS miały w układzie 35 powiatów województwa wielkopolskiego charakter negatywny $(\mathrm{r}=-0,587)$ oraz poziomem poparcia dla KE charakter pozytywny $(r=+0,575)$. Podobny charakter miały powiązania przestrzenne pomiędzy odsetkiem dzieci pozamałżeńskich w 2014 r., który jest pewnym miernikiem swobód obyczajowych, a poziomem poparcia dla PiS $(r=-0,520)$ oraz poziomem poparcia dla KE $(r=+0,508)$. Również odległość drogowa ośrodka powiatowego od stolicy województwa stymulowała poziom poparcia zarówno dla PiS $(r=-0,601)$, jak i dla KE $(r=-0,496)$. Wszystkie określone $w$ tej analizie współczynniki korelacji były istotne statystycznie na poziomie $\alpha=0,01$.

\section{Literatura}

Bartkowski J. 2003. Tradycja i polityka. Wpływ tradycji kulturowych polskich regionów na współczesne zachowania społeczne i polityczne. Wydawnictwo Akademickie Żak, Warszawa.

Chojnicki Z., Czyż T. 1978. Podstawy metodologiczne zastosowania analizy czynnikowej. [W:] Z. Chojnicki, T. Czyż, J. Parysek, W. Ratajczak (red.), Badania przestrzennej struktury społeczno-ekonomicznej Polski metodami czynnikowymi. PWN, Warszawa-Poznań, s. 7-19.

Czyż T. 2016. Metoda wskaźnikowa w geografii społeczno-ekonomicznej. Rozwój Regionalny i Polityka Regionalna, 34: 9-19. 
Grajcar R. 2009. System wyborczy do Parlamentu Europejskiego w Polsce. [W:] R. Grajcar, W. Wojtasik (red.), Wybory do Parlamentu Europejskiego w Polsce. Wyd. Remar, Sosnowiec, s. 51-73.

Krawczyk P., Matykowski R., Tobolska A. 1993. Podstawowe problemy geografii elektoralnej: przykłady polskie. Streszczenia referatów, 42 Zjazd PTG, Kielce, s. 144-146.

Kubiak H. 1999. Wartość poznawcza genius loci jako kategorii wyjaśniającej zachowania wyborcze mieszkańców południowej Małopolski. [W:] P. Sztompka (red.), Imponderabilia wielkiej zmiany. Mentalność, wartości i więzi społeczne czasów transformacji. PWN, Warszawa-Kraków, s. 395-417.

Kwiatkowski P. 1984. Ideologia regionalizmu w Polsce międzywojennej. Kultura i Społeczeństwo, 4: $143-156$.

Lipset S.M., Rokkan S. 1967. Party systems and voter alignments. Cross-national perspectives (Osie podziałów, systemy partyjne oraz afiliacje wyborców). [W:] J. Szczupaczyński (red.), Władza i społeczeństwo. Antologia tekstów z zakresu socjologii polityki. Wydawnictwo Naukowe Scholar, Warszawa, s. 89-122.

Malikowski M. 2001. Subiektywne aspekty więzi regionalnej w województwie podkarpackim. Tożsamość i identyfikacja regionalna. Regiony Polski, 1(2): 83-109.

Matykowski R., Kulczyńska K. 2016. Wybory do Sejmu w 2015 r. w województwie wielkopolskim: odmienności przestrzenne w kontekście subregionalnym i lokalnym. Rozwój Regionalny i Polityka Regionalna, 36: 163-178.

Matykowski R., Tobolska A. 1996. Geografia elektoralna. Geografia w Szkole, 4(250): 206-214.

Prawelska-Skrzypek G., Matykowski R. 2001. Współczesne oblicza regionalizmu: analiza przypadków w Polsce. Regiony Polski, 2(3): 45-73.

Rokkan S. 1970. Citizens. Elections. Parties. Universitetsforlaget, Oslo.

Rykiel Z. 1985. Badania świadomości regionalnej - przykład regionu katowickiego. Przegląd Geograficzny, 1: 7-58.

Skorowski H. 1999. Europa regionu. Regionalizm jako kategoria aksjologiczna. Wydawnictwo Fundacji ATK, Warszawa.

Sowa K. 1998. Galicja jako fenomen historyczny i socjologiczny. [W:] W. Świątkiewicz (red.), Regiony i regionalizmy w Polsce współczesnej. Instytut Socjologii Uniwersytetu Śląskiego i Polskie Towarzystwo Socjologiczne, Katowice, s. 27-47.

Surazska W. 1994. The consequences of post-war resetlements on the electoral behaviour in Poland. Meeting of the IGU „Geography of mass politics in post-Communist Europe”. Hruba Skala, 18-21 August (materiał powielany).

Taylor P.J., Johnson R.J. 1979. Geography of Elections. Penguin, London.

Wódz J., Wódz K. 1995. Regionalizm, dzielnicowość, tożsamość narodowa. Próba socjologicznej analizy dynamiki zjawisk. [W:] M.W. Wanatowicz (red.), Regionalizm a separatyzm - historia i współczesność. Śląsk na tle innych obszarów. Wydawnictwo Uniwersytetu Śląskiego, Katowice, s. $180-190$.

Zarycki T. 1997. Nowa przestrzeń społeczno-polityczna Polski. Studia Regionalne i Lokalne 23(56).

\title{
Elections to the European Parliament in 2019 in the Wielkopolska voivodeship: spatial differences in the subregional pattern
}

\begin{abstract}
The aim of this paper is to characterise the political orientations of the Wielkopolska region electorate revealed in the elections to the European Parliament on May 26 2019, in a territorial pattern of 35 poviats. Based on the ratio of support ratios for the two leading election committees, the areas of advantage of the European Committee and the predominance of support for Law and Justice were determined. Attention was also paid to the role of outsiders candidates in various parts of the voivodeship, considered as an example of a community with strong regionalist attitudes.
\end{abstract}

Key words: elections to the European Parliament, electoral results spatial differences of electoral results, outsiders candidates and regionalist attitudes, Wielkopolska region 